\title{
Evaluation of Three Practical Methods for Estimating Daily Solar Radiation in Dry Climates
}

\author{
F. Castellví*
}

\author{
Department of Environmental and Soil Science. University of Lleida. Rovira Roure 177, 25198 Lleida, Spain
}

\begin{abstract}
Three practical methods for estimating daily solar radiation in dry climates with air temperature and precipitation data as input were evaluated. The three equations only partially explained second order statistics such as variance and different correlations, so the interdependence with primary weather variables such as the daily maximum and minimum temperatures was not fully captured. The equations, however, may be useful for calculations that require solar radiation as input, such as the daily reference evapotranspiration according to Priestley-Taylor equation using the FAO guidelines expert consultation.
\end{abstract}

\section{INTRODUCTION}

Solar radiation, Rs, is the main source of energy that drives physical, chemical and biological processes [1]. It is the main component of net solar radiation, which plays a key role in soil-vegetation-atmosphere processes and in estimating evapotranspiration rates, which play a key role in the surface water balance and energy balance calculations. Therefore, knowledge of Rs is useful for agro-ecological studies such as plant-growth modeling. During recent decades, the number of weather stations recording Rs has increased dramatically, but Rs is rarely measured in some countries and it is often not recorded at a site of interest [2,3] even in countries with good meteorological data [4]. Therefore, methods for estimating Rs are sometimes valuable. Rs estimates obtained from expressions involving bright sunshine hours have proven accurate [5-9]. Bright sunshine hour data are not always available, however, and expressions requiring weather variables (e.g., precipitation and temperature) as primary input have been proposed [10-16]. Using primary weather data rather than other variables (e.g., type of clouds, cloud cover, humidity, etc.) as input is desirable because (1) weather stations with long series of temperature and precipitation are common and (2) daily air temperature and rainy days can be simulated from climate parameters that typically are available [17-20]. The objective of this study is to evaluate three methods for estimating daily Rs in dry climates that require only primary weather data as input. The methods include Hargreaves et al.'s equation [21], which requires air temperature data, Bristow and Campbell's equation [22], which requires precipitation occurrence and air temperature, and Castellvi's method [23] that requires precipitation occurrence and an expression for estimating Rs on a monthly basis.

\footnotetext{
*Address correspondence to this author at the Department of Environmental and Soil Science. University of Lleida. Rovira Roure 177, 25198 Lleida, Spain; Tel: 0034-973-702 620; Fax: 0034- 973-702 613;
}

E-mail: F-Castellvi@macs.udl.es

\section{METHODS}

Daily Rs can be estimated from an integrated attenuation factor in the Beer's Law [1, 24]

$R s=\tau R a$

where $\mathrm{Ra}$ is the daily extraterrestrial solar radiation and $\tau$ is the daily weighted mean atmospheric transmittance (from the top of the atmosphere to the ground). Daily values for Ra can be determined from the latitude and day of year as shown in the appendix (Eq. A1). However, $\tau$ is difficult to quantify because the solar energy attenuation depends on complex physical and chemical processes. Air temperaturebased expressions for estimating $\tau$ have been proposed [21,22]. On a daily basis, air temperature amplitude should be positively correlated with solar radiation because, according to the simplified surface energy-balance equation, the sum of sensible and latent heat flux depends mainly on the net available energy at the surface, which is well correlated with Rs [25], and the time air temperature trace measured at one level contains the essential information for estimating sensible heat flux [26]. Based on this reasoning, over an extensive and uniform terrain, since Ra changes little in the short term and the sensible and latent heat fluxes are mainly local, the daily temperature fluctuations are related to $\tau$.

\subsection{The Bristow and Campbell (1984) Equation}

This equation relates the daily atmospheric transmittance with the temperature amplitude, $\Delta \mathrm{T}_{\mathrm{k}}$, as follows

$\Delta T_{k}=T_{x, k}-\frac{T_{n, k}+T_{n, k+1}}{2}$

where $T_{x, k}$ and $T_{n, k}$ are the maximum and minimum temperatures for day $\mathrm{k}$ and $\mathrm{T}_{\mathrm{n}, \mathrm{k}+1}$ is the minimum temperature for day $\mathrm{k}+1$. The mean minimum temperature for days $\mathrm{k}$ and $\mathrm{k}+1$ smoothes sharp drops or increases in the temperature amplitude and accounts for large-scale advection events associated with cold or warm air mass passage. For sites in tropical latitudes the correction is often unnecessary, and $\Delta \mathrm{T}_{\mathrm{k}}=\mathrm{T}_{\mathrm{x}, \mathrm{k}}-\mathrm{T}_{\mathrm{n}, \mathrm{k}}$. 
At some mid-latitude sites, $\Delta \mathrm{T}_{\mathrm{k}}$ may require a correction factor for rainy days to account for sharp drops in solar radiation associated with clouds passage. Two expressions for $\Delta \mathrm{T}_{\mathrm{k}}$ were proposed.

For the first rainy day in a wet period;

$\Delta \mathrm{T}_{\mathrm{k}}=\mathrm{T}_{\mathrm{x}, \mathrm{k}}-0.75\left(\mathrm{~T}_{\mathrm{n}, \mathrm{k}}+\mathrm{T}_{\mathrm{n}, \mathrm{k}+1}\right)$

When $\Delta \mathrm{T}_{\mathrm{k}}$ is less than $\Delta \mathrm{T}_{\mathrm{k}-1}$ by more than $2^{\circ} \mathrm{C}$ and day $\mathrm{k}+1$ correspond to a rainy day:

$\Delta \mathrm{T}_{\mathrm{k}}=\mathrm{T}_{\mathrm{x}, \mathrm{k}}-0.25\left(\mathrm{~T}_{\mathrm{n}, \mathrm{k}}+\mathrm{T}_{\mathrm{n}, \mathrm{k}+1}\right)$

The daily Rs estimates are determined using the following expression

$R s_{k}=\tau_{x}\left[1-\exp \left(a_{1} \Delta T_{k}^{a_{2}}\right)\right] R_{a, k}$

where $\tau_{\mathrm{x}}$ is the daily maximum atmospheric transmittance and $\mathrm{a}_{1}$ and $\mathrm{a}_{2}$ are site-specific coefficients. At non-polluted sites with moderate elevation, the value $\tau_{\mathrm{x}}=0.75$ provides good accuracy $[27,28]$. Often, $\tau_{\mathrm{x}}$ ranges from 0.7 to 0.8 and it has been suggested that stations recording $\tau_{\mathrm{x}}$ out of this range may require maintenance [10]. Equation (5) has proven to perform well on a monthly basis [14].

\subsection{The Hargreaves et al. (1985) Equation}

The authors proposed Eq. 6 to estimate Rs on a monthly basis; however, Eq. 6 also works well on a daily basis [11, 13]. It was considered the best of several equations for estimating Rs using primary weather data [15].

$\mathrm{Rs}_{\mathrm{k}}=\mathrm{b}_{2}+\mathrm{b}_{1} \mathrm{Ra}_{, \mathrm{k}}\left(\Delta \mathrm{T}_{\mathrm{k}}\right)^{0.5}$

where, $b_{1}$ and $b_{2}$ are site-specific coefficients and $\Delta T_{\mathrm{k}}$ is the air thermal amplitude for day $\mathrm{k}, \Delta \mathrm{T}_{\mathrm{k}}=\left(\mathrm{T}_{\mathrm{x}, \mathrm{k}}-\mathrm{T}_{\mathrm{n}, \mathrm{k}}\right)$.

\subsection{The Castellvi (2001) Method}

The daily Rs estimates are conditioned to the precipitation status of the day (i.e., dry or wet) to better capture the actual variability. The method requires the monthly frequency of wet days and an equation for estimating the monthly solar radiation. The following set of equations were derived for estimating daily Rs on a dry or wet day:

For dry days:

$R s_{k}= \begin{cases}c_{1}\left(1+f_{w e t}\right) R s_{m, k} & \text { if } f_{w e t}>0 \\ R s_{m, k} & \text { if } f_{\text {wet }}=0\end{cases}$
For wet days:

$R s_{k}= \begin{cases}\left(1-c_{1}\left(1-f_{w e t}^{2}\right)\right)\left(f_{w e t}\right)^{-1} R s_{m, k} & \text { if } f_{w e t}>\left(1-c_{1}\right) \\ c_{2}\left(R s_{m, k}\right)+c_{3} & \text { if } 0<f_{w e t}<\left(1-c_{1}\right)\end{cases}$

where $f_{\text {wet }}$ is the frequency of wet days in the month, $m$ and $\mathrm{Rs}_{\mathrm{m}, \mathrm{k}}$ is the selected equation for estimating the monthly Rs. The method refines the daily Rs estimates determined from $\mathrm{Rs}_{\mathrm{m}, \mathrm{k}}$ which are obtained with the input required on a daily basis, and $c_{1}, c_{2}$ and $c_{3}$ are site-specific coefficients to be adjusted monthly. Note that calibration of Eqs. (7) and (8) requires the mean monthly Rs for dry and wet days, respectively.

\section{MATERIALS AND PROCEDURE FOR COMPARI- SON}

A set of five weather stations with daily precipitation, maximum and minimum air temperature, and solar radiation data were used. Table 1 lists the locations, the annual Rs and humidity features which are typical for dry to temperate climates. Bristow and Campbell's and Hargreaves et al.'s equations were adjusted daily and monthly. The latter were used in the Castellvi's method.

All the climate series in monthly basis passed the run test at $10 \%$ level of significance to check for homogeneity $[12,29]$. Even though, long homogenous climate series are desireable, 10 years of daily Rs series tends to capture most of the variability. All the data (Table 1) were used to adjust the Rs equations; consequently, the coefficients determined were representative of the site. To evaluate the reliability of the estimates, the slope of the linear fitting forced through the origin, $\mathrm{p}$, the coefficient of determination, $\mathrm{R}^{2}$, the root mean square error, RMSE (MJ m${ }^{-2}$ day ${ }^{-1}$ ), and the nonparametric Kolmogorov-Smirnov test [30] for different cumulative distribution functions, CDF, in monthly, seasonal, and annual periods were computed. A lack of realism in the estimates is present when the actual inter-correlation and persistence inherent in meteorological data is not performed. Therefore, different auto and cross correlations between daily maximum and minimum air temperatures and solar radiation were compared for seasonal and annual periods. The null hypothesis that two independent populations have the same correlation was tested [30]. The test was applied to evaluate the capability of the estimates in reproducing (1) the auto-correlation of the daily Rs lagged one day and (2) the cross-correlation between daily $\mathrm{Rs}$ and the daily maximum and minimum air temperatures, respectively, lagged zero and one days. The daily reference evapotranspiration, $\mathrm{ET}_{\mathrm{o}}$, based

Table 1. Location, Years of Data, Annual Solar Radiation (MJ $\mathbf{m}^{-2}$ Day $^{-1}$ ) and Humidity Features. Prec is Annual Precipitation $(\mathrm{mm}), \mathbf{f}_{\text {wet }}$ is the Frequency of Rainy Days, and, H.Index, is a Humidity Index

\begin{tabular}{|ll|ccccc|}
\hline & Location & Period & Prec & f & H. Index & Rs \\
\hline \hline Fresno & $\left(36^{\circ} 49^{\prime}\right.$ N, Ca, USA $)$ & $1991-2000$ & 487 & 0.12 & 0.29 \\
Gerber & $\left(40^{\circ} 31^{\prime}\right.$ N, Ca, USA $)$ & $1991-2000$ & 492 & 0.18 & 0.43 & 17.37 \\
Kesterson & $\left(37^{\circ} 14^{\prime}\right.$ N, Ca, USA $)$ & $1991-2000$ & 480 & 0.12 & 0.29 & 17.05 \\
Lleida & $\left(41^{\circ} 36^{\prime}\right.$ N, Spain $)$ & $1994-2002$ & 342 & 0.11 & 0.63 & 14.01 \\
Montpellier & $\left(43^{\circ} 60^{\prime}\right.$ N, France $)$ & $1985-1994$ & 484 & 0.24 & 0.98 & 13.73 \\
\hline
\end{tabular}

H.Index is defined as Prec over the annual potential evapotranspiration [35]. 
on Priestley and Taylor's equation [31], was determined as shown in the appendix. The $\mathrm{ET}_{\mathrm{o}}$ as a function that involves different variables, was used to evaluate the global performance of the Rs estimates and its inter-correlation with the remainder of the observed variables required as input (maximum and minimum air temperature). Hereafter, observed and estimated $\mathrm{ET}_{\mathrm{o}}$ refers to values determined using the observed and estimated Rs as input in Eq. (A5). The Kolmogorov-Smirnov test was applied to compare the CDF for the $\mathrm{ET}_{\mathrm{o}}$ for annual, seasonal, and monthly periods. All the tests were applied at the 5\% level of significance.

The Rs estimates were determined for the Bristow and Campbell (1985) equation adjusted daily (B\&C_d) and monthly (B\&C_m), the Hargreaves et al. (1984) equation adjusted daily (H_d) and monthly (H_m), and the Castellvi (2001) method implementing H_m (H_C) and B\&C_m (B\&C_C). A day was considered wet when the precipitation was greater than $0.2 \mathrm{~mm}$ (the rain-gauge error).

\section{RESULTS}

Table 2 shows the coefficients adjusted to estimate the daily and monthly solar radiation for all equations and the corresponding $\mathrm{p}, \mathrm{R}^{2}$ and RMSE values. For Hargreaves et al. (1984) equation, the daily and monthly coefficients were similar regardless of the location. The spatial standard deviations for coefficient $b_{1}$ in a daily and monthly basis were 0.0054 and 0.0083 , respectively, and for $b_{2}$ were 0.23 and 0.32 , respectively. Such performance was not observed with the other equations. All $b_{2}$ coefficients were negative. Therefore, in Eq. (6) a boundary for small daily thermal amplitudes is required. The minimum Rs observed in the month was set when Rs estimates were negative. For Bristow and Campbel (1985) equation, $\tau_{\mathrm{x}}$ ranged from 0.75 to 0.77 (not shown in Table 2), and the daily and monthly coefficients were dissimilar and site-specific. This corroborates observations in Australia [13]. Castellvi (2001) method is local by nature because the coefficients are highly dependent on months where $f_{\text {wet }}$ is close to zero. It was found, however, that coefficient $c_{1}$ was similar for all sites. The mean value was $c_{1}=0.94$ with a spatial standard deviation of 0.015 . Except at Lleida, the $\mathrm{p}, \mathrm{R}^{2}$ and RMSE values indicated that the Hargreaves et al. (1984) equation compared better with the observed data than Bristow and Campbell (1985) equation on both a daily and monthly basis. The Castellvi (2001) method performed better implementing $\mathrm{H} \_\mathrm{m}$ than $\mathrm{B} \& \mathrm{C} \_\mathrm{m}$, and H_C gave slightly better results than H_d. Table $\mathbf{3}$ shows the number of daily Rs CDF that accepted the null hypothesis in monthly, seasonal, and annual periods. The performance was generally poor. In general, the means were captured, but the standard deviations were difficult to explain. Except at Lleida, H_C performed reasonably well. Recall that the main idea behind the Castellvi (2001) method was to better capture the variance. Table $\mathbf{3}$ shows better performance for H_m than for B\&C_m at all locations but Lleida. Similar results were shown for temperate, dry and arid climates using other equations to estimate daily Rs [3]. Table 4 shows the observed annual cross and auto correlations and the locations where the null hypothesis was accepted. Table 5 gives the number of tests that accepted the null hypothesis for seasonal cross and auto correlations. A total of 20 tests per location were performed corresponding to five correlations per season. Whatever the equation and location, Tables $\mathbf{4}$ and $\mathbf{5}$ showed poor performance. All equations were unable to reproduce the correlation between the daily maximum temperature and solar radiation on an annual basis (Table 4) or seasonal basis (not shown). The equations replicated about $30 \%$ of the total number of correlations on an annual and seasonal basis. H_C and B\&C_C performed best for the Rs lagged one day on an annual (Table 4) and seasonal basis (not shown). Table $\mathbf{5}$ shows that, except at Monpellier and Lleida, B\&C_d did the same or better performance than the other equations. Therefore, $B \& C$ d is in general more realistic, but its superiority was constrained to one station (Gerber). The limited capability in reproducing the actual interdependence between variables indicates that these equations may not be reliable to fill gaps $[19,11,13]$ or to expand short series of daily solar radiation to locally calibrate the auto, cross and lagged correlations required as input in weather simulation models based on a quasistationary auto-regressive multivariate process [23, 32-34]. Table 6 shows the number of tests accepting the null hypothesis for the monthly, seasonal and annual $\mathrm{ET}_{\mathrm{o}} \mathrm{CDF}$. In contrast with the results shown in Tables $\mathbf{3}, \mathbf{4}$ and $\mathbf{5}$, whatever the equation, the number of tests accepted was high. Though not directly comparable, because the different equations used to estimate Rs and $\mathrm{ET}_{\mathrm{o}}$, such performance has been shown for dry climates [3]. Table $\mathbf{6}$ shows that, in general, the Hargreaves et al. (1984) equation performed better than Bristow and Campbel (1985) equation. According to the humidity index (Table 1), the drier the climate the better the performance of H_d and H_m. For the remaining equations, this pattern was not clear. Except at Lleida, Table 6 shows that, H_C performed slightly better than H_m and H_d. The worst performance by Eq. (8) occurred at Lleida (Fig. 1). Lleida is located within the Ebro river basin in Northern Spain. It has an annual mean of 58 foggy days and has climate influences from the Pyrenees barrier (North) and an arid region (Zaragoza, North-West), which is aligned in the prevailing wind direction within the basin. Because the monthly solar radiation for wet days may be difficult to estimate, some outliers can be obtained.

\section{SUMMARY, DISCUSSION AND CONCLUDING REMARKS}

In general, daily Rs estimates using Hargreaves et al. (1984) equation performed slightly better than the Bristow and Campbell (1985) equation. Hargreaves et al. (1984) equation may be adjusted either using daily or monthly data to estimate daily Rs and it appears useful for spatial extrapolation because the coefficients involved were similar regardless of the location. These results, however, rely on statistics rather than physics. In nature, it is not necessary for Rs to be similar in different locations. In the Hargreaves et al. (1984) equation, all $b_{2}$ coefficients obtained were negative (Table 2). Therefore, Eq. (6) lacks physical meaning. A boundary for small temperature amplitudes is required. The Bristow and Campbell (1985) equation was best when it was adjusted 
Table 2. Daily and Monthly Coefficients Determined for All Methods. Slope of Linear Regression Through the Origin, p, the Coefficient of Determination, $R^{2}$, and the Root Mean Square Error RMSE (MJ m $^{-2}$ Day $^{-1}$ ) Comparing the Daily Rs Estimates Against the Actual Data

\begin{tabular}{|c|c|c|c|c|c|c|c|c|c|c|c|}
\hline \multicolumn{2}{|c|}{$\begin{array}{l}\text { Location } \\
\text { Calibration and Statistics: }\end{array}$} & \multicolumn{2}{|c|}{$\begin{array}{l}\text { Fresno } \\
\text { Daily Monthly }\end{array}$} & \multicolumn{2}{|c|}{$\begin{array}{l}\text { Gerber } \\
\text { Daily Monthly }\end{array}$} & \multicolumn{2}{|c|}{$\begin{array}{l}\text { Kesterson } \\
\text { Daily Monthly }\end{array}$} & \multicolumn{2}{|c|}{$\begin{array}{l}\text { Montpellier } \\
\text { Daily Monthly }\end{array}$} & \multicolumn{2}{|c|}{$\begin{array}{l}\text { Lleida } \\
\text { Daily Monthly }\end{array}$} \\
\hline \multirow{5}{*}{ Uే } & $a_{1}$ & -0.21 & -0.01 & -0.65 & -0.01 & -0.14 & -0.02 & -0.11 & -0.05 & -0.12 & -0.04 \\
\hline & $a_{2}$ & 1.80 & 1.84 & 1.6 & 1.85 & 1.87 & 1.50 & 1.90 & 1.50 & 2.0 & 2.0 \\
\hline & $\mathrm{p}$ & 0.87 & 1.13 & 0.89 & 1.15 & 0.90 & 1.16 & 0.70 & 1.11 & 0.96 & 0.96 \\
\hline & $\mathrm{R}^{2}$ & 0.84 & 0.69 & 0.88 & 0.70 & 0.84 & 0.64 & 0.78 & 0.64 & 0.82 & 0.89 \\
\hline & RMSE & 2.89 & 4.89 & 2.81 & 4.91 & 2.86 & 5.49 & 5.44 & 4.96 & 3.39 & 2.69 \\
\hline \multirow{5}{*}{ 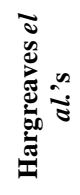 } & $b_{1}$ & 0.18 & 0.19 & 0.18 & 0.18 & 0.17 & 0.17 & 0.18 & 0.18 & 0.17 & 0.17 \\
\hline & $b_{2}$ & -1.60 & -1.20 & -1.65 & -1.85 & -1.39 & -1.70 & -1.07 & -1.10 & -1.47 & -1.53 \\
\hline & $\mathrm{p}$ & 0.98 & 0.98 & 0.98 & 0.97 & 0.98 & 0.98 & 0.95 & 0.94 & 1.03 & 0.96 \\
\hline & $\mathrm{R}^{2}$ & 0.91 & 0.90 & 0.80 & 0.90 & 0.90 & 0.89 & 0.80 & 0.79 & 0.75 & 0.87 \\
\hline & RMSE & 2.65 & 2.66 & 2.80 & 2.81 & 2.74 & 2.75 & 3.42 & 3.44 & 3.89 & 2.76 \\
\hline \multirow{7}{*}{ 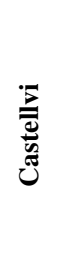 } & $c_{1}$ & \multirow{3}{*}{\multicolumn{2}{|c|}{$\begin{array}{r}0.96 \\
1.05 \\
-3.70\end{array}$}} & \multirow{3}{*}{\multicolumn{2}{|c|}{$\begin{array}{r}0.95 \\
1.29 \\
-10.95\end{array}$}} & \multirow{3}{*}{\multicolumn{2}{|c|}{$\begin{array}{r}0.96 \\
0.94 \\
-0.72\end{array}$}} & \multirow{3}{*}{\multicolumn{2}{|c|}{$\begin{array}{l}0.91 \\
0.49\end{array}$}} & \multicolumn{2}{|c|}{0.91} \\
\hline & $c_{2}$ & & & & & & & & & 0. & \\
\hline & $c_{3}$ & & & & & & & & & & \\
\hline & Method: & H_C & B\&C_C & H_C & B\&C_C & H_C & B\&C_C & H_C & $3 \& C \_C$ & H_C & B\&C_C \\
\hline & $\mathrm{p}$ & 1.00 & 1.16 & 1.00 & 1.12 & 1.00 & 1.19 & 0.98 & 1.15 & 1.00 & 0.98 \\
\hline & $\mathrm{R}^{2}$ & 0.89 & 0.69 & 0.88 & 0.71 & 0.88 & 0.59 & 0.81 & 0.76 & 0.89 & 0.69 \\
\hline & RMSE & 2.9 & 5.7 & 3.1 & 5.6 & 2.8 & 6.3 & 3.45 & 5.0 & 3.5 & 2.7 \\
\hline
\end{tabular}

Table 3. Number of Observed Daily Rs Cumulative Distribution Functions Replicated in a Monthly, m, Seasonal, s, and Annual, a, Periods for Each Equation

\begin{tabular}{|c|c|c|c|c|c|c|c|c|c|c|c|c|c|c|c|}
\hline $\begin{array}{l}\text { Location: } \\
\text { Method: }\end{array}$ & \multicolumn{3}{|c|}{ Fresno } & \multicolumn{2}{|c|}{ Gerber } & & \multicolumn{3}{|c|}{ Kesterson } & \multicolumn{3}{|c|}{ Montpellier } & \multicolumn{2}{|c|}{ Lleida } & $\mathbf{a}$ \\
\hline Bristow \& Campbell's daily & 2 & 0 & 3 & 0 & 0 & 1 & 2 & 0 & 3 & & 0 & & & 0 & 3 \\
\hline Bristow \& Campbell's monthly & 0 & 0 & 0 & 0 & 0 & 0 & 0 & 0 & 0 & 0 & 0 & 0 & 1 & 0 & 6 \\
\hline Hargreaves el al.'s daily & 5 & 0 & 7 & 3 & 0 & 8 & 6 & 0 & 5 & 3 & 0 & 5 & 1 & 0 & 5 \\
\hline Hargreaves el al.'s monthly & 6 & 0 & 6 & 3 & 0 & 8 & 6 & 0 & 4 & 1 & 0 & 4 & 1 & 0 & 5 \\
\hline Castellvi-Bristow\&Campbell's & 0 & 0 & 0 & 0 & 0 & 0 & 0 & 0 & 0 & 0 & 0 & 1 & 2 & 3 & 2 \\
\hline Castellvi-Hargreaves el al.'s & 7 & 2 & 8 & 6 & 3 & 9 & 7 & 1 & 7 & 8 & 3 & 9 & 1 & 0 & 4 \\
\hline
\end{tabular}

Table 4. Observed Serial and One-Day Lag Annual Correlations Between the daily Maximum, Tx, or Minimum, Tn, Temperatures and the Solar Radiation, Rs, at Each Location, and where these Correlations were Replicated by Each Equation. Sub-Index 0 and 1 Denotes Correlations Lagged Zero Days and One Day, Respectively

\begin{tabular}{|c|c|c|c|c|c|c|}
\hline \multicolumn{2}{|c|}{ Location: } & \multicolumn{5}{|c|}{$(\mathbf{T x}, \mathbf{R s})_{0}(\mathrm{Tn}, \mathbf{R s})_{0}(\mathrm{Tx}, \mathbf{R s})_{1}(\mathrm{Tn}, \mathbf{R s})_{1}(\mathrm{Rs}, \mathbf{R s})_{1}$} \\
\hline $\begin{array}{l}\text { Fresno } \\
\text { Gerber } \\
\text { Kesterson } \\
\text { Montpellier } \\
\text { Lleida }\end{array}$ & $\begin{array}{l}\text { (F) } \\
(\mathrm{G}) \\
(\mathrm{K}) \\
(\mathrm{M}) \\
(\mathrm{Ll})\end{array}$ & $\begin{array}{l}0.281 \\
0.489 \\
0.307 \\
0.353 \\
0.399\end{array}$ & $\begin{array}{l}-0.329 \\
-0.193 \\
-0.306 \\
-0.313 \\
-0.289\end{array}$ & $\begin{array}{l}0.240 \\
0.326 \\
0.233 \\
0.161 \\
0.272\end{array}$ & $\begin{array}{l}-0.200 \\
-0.141 \\
-0.236 \\
-0.317 \\
-0.188\end{array}$ & $\begin{array}{l}0.444 \\
0.425 \\
0.498 \\
0.394 \\
0.402\end{array}$ \\
\hline \multicolumn{2}{|l|}{ Equation: } & \multicolumn{5}{|c|}{ Observed correlation replicated: } \\
\hline \multicolumn{2}{|c|}{$\begin{array}{l}\text { Bristow \& Campbell's daily } \\
\text { Bristow \& Campbell's monthly }\end{array}$} & \multicolumn{3}{|c|}{$\begin{array}{l}\mathrm{G} \\
\mathrm{G}\end{array}$} & \multicolumn{2}{|l|}{$\mathrm{G}, \mathrm{Ll}$} \\
\hline \multicolumn{2}{|c|}{ Hargreaves el al.'s daily } & \multicolumn{5}{|c|}{$\mathrm{Ll}$} \\
\hline \multicolumn{2}{|c|}{ Hargreaves el al.'s monthly } & \multicolumn{5}{|c|}{$\mathrm{Ll}$} \\
\hline \multirow{2}{*}{\multicolumn{2}{|c|}{$\begin{array}{l}\text { Castellvi-Bristow\&Campbell's } \\
\text { Castellvi-Hargreaves } \text { el al.'s }\end{array}$}} & & G & M & G & $\mathrm{G}, \mathrm{K}, \mathrm{M}$ \\
\hline & & & M & Ll & $\mathrm{Ll}$ & $\mathrm{K}, \mathrm{M}, \mathrm{Ll}$ \\
\hline
\end{tabular}


Table 5. Number of Serial and One-Day Lag Seasonal Correlations Replicated by Each Equation

\begin{tabular}{|c|c|c|c|c|c|c|}
\hline Location: & Fresno & Gerber & Kesterson & Montpellier & Lleida & Total* \\
\hline Bristow \& Campbell's daily & 4 & 9 & 6 & 8 & 6 & 33 \\
\hline Bristow \& Campbell's monthly & 3 & 4 & 4 & 8 & 5 & 24 \\
\hline Hargreaves el al.'s daily & 2 & 5 & 6 & 3 & 9 & 25 \\
\hline Hargreaves el al.'s monthly & 2 & 5 & 6 & 3 & 9 & 25 \\
\hline Castellvi-Bristow\&Campbell's & 5 & 7 & 2 & 6 & 7 & 27 \\
\hline Castellvi-Hargreaves el al.'s & 4 & 7 & 4 & 8 & 7 & 30 \\
\hline
\end{tabular}

$*$ A total of 100 tests were conducted per location.

Table 6. Number of ET $\mathbf{E}_{\mathbf{0}}$ Cumulative Distribution Functions Replicated in a Monthly, m, Seasonal, s, and Annual, a, Periods

\begin{tabular}{|c|c|c|c|c|c|c|c|c|c|c|c|c|c|c|c|c|c|c|}
\hline \multirow{2}{*}{ Method } & \multicolumn{3}{|c|}{ Fresno } & \multicolumn{3}{|c|}{ Gerber } & \multicolumn{3}{|c|}{ Kesterson } & \multicolumn{3}{|c|}{ Montpellier } & \multicolumn{3}{|c|}{ Lleida } & \multicolumn{3}{|c|}{ All Data } \\
\hline & $\mathbf{m}$ & $\mathbf{s}$ & $\mathbf{a}$ & $\mathbf{m}$ & $\mathbf{s}$ & $\mathbf{a}$ & m & $\mathbf{S}$ & $\mathbf{a}$ & $\mathbf{m}$ & $\mathbf{s}$ & $\mathbf{a}$ & $\mathbf{m}$ & $\mathbf{s}$ & $\mathbf{a}$ & $\mathbf{m}$ & $\mathbf{s}$ & $\mathbf{a}$ \\
\hline Bristow\& Campbell's daily & 8 & 2 & 4 & 8 & 2 & 5 & 9 & 3 & 5 & 10 & 3 & 8 & 10 & 4 & 10 & 9 & 3 & 5 \\
\hline Bristow\& Campbell's monthly & 8 & 2 & 2 & 8 & 2 & 2 & 8 & 2 & 2 & 10 & 3 & 6 & 9 & 3 & 9 & 8 & 2 & 5 \\
\hline Hargreaves el al.’s daily & 10 & 3 & 8 & 10 & 3 & 8 & 11 & 4 & 8 & 10 & 3 & 10 & 12 & 4 & 10 & 10 & 3 & 8 \\
\hline Hargreaves el al.'s monthly & 10 & 3 & 8 & 10 & 3 & 8 & 9 & 4 & 7 & 10 & 3 & 10 & 10 & 3 & 9 & 9 & 3 & 8 \\
\hline Castellvi-Bristow \& Campbell's & 7 & 1 & 1 & 7 & 1 & 1 & 7 & 1 & 0 & 8 & 2 & 3 & 10 & 3 & 8 & 7 & 1 & 3 \\
\hline Castellvi-Hargreaves el al.'s & 11 & 4 & 8 & 10 & 4 & 10 & 11 & 4 & 9 & 11 & 4 & 10 & 10 & 3 & 9 & 10 & 4 & 9 \\
\hline
\end{tabular}

(a)

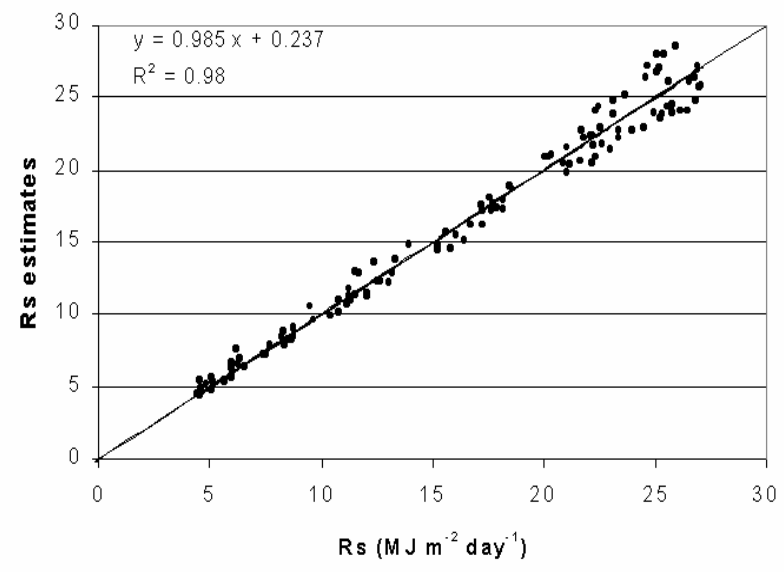

(b)

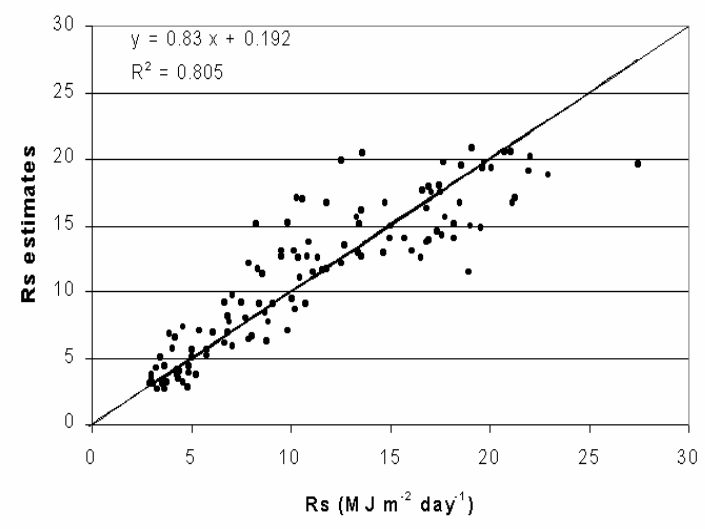

Fig. (1). Monthly solar radiation at Lleida. Performance for (a) dry days, Eq. (7), and (b) wet days, Eq. (8). The linear regression analysis and the 1:1 line are shown. daily and calibration was site-specific. The latter must be interpreted as an indicator that Bristow and Campbell's is better grounded than Hargreaves et al.'s equation. For small daily temperature amplitudes (foggy, cloudy, and rainy days), Eq. (5) does not provide negative Rs values. For high temperature amplitudes (clear sky days), Rs values are related with the mean air pollution at the site. These boundaries tend to constraint the empirical coefficients involved in Eq. (5) at a site. The latter may explain the slightly better performance observed in reproducing the weather interdependence between variables. Further research at other locations with dry climates and a wider range of latitudes is required to test the superiority of the Bristow and Campbell (1985) method on this crucial aspect. The Castellvi (2001) method is local and, for some wet days, the estimates may require smoothing. All equations were unable to fully reproduce the $\mathrm{CDF}$ and to preserve the interdependence for maximum and minimum air temperatures for monthly, seasonal, and annual periods. For long-tem studies, however, the equations are useful for estimating the daily reference evapotranspiration evaluated as a portion of the radiative term in the Penman equation [25]. For the five dry climates analyzed, the results indicate that (1) simple equations to estimate solar radiation can partially explain the main climate patterns but it does not necessarily means that they are not useful, (2) local studies are best suited using Hargreaves et al. (1984) equation combined with the Castellvi (2001) method, and (3) the Hargreaves et al. (1984) equation is better suited for non-local studies, but caution is required because calibration indicates a lack of physical meaning. Further research covering a wider range of climates is required to generalize these founds.

\section{ACKNOWLEDGEMENTS}

The author sincerely thanks R.L Snyder, Asun, Carla and Tania for their help providing different facilities The review 
task was constructive, competent and provided useful comments. This work has been supported by TRANSCLA (CGL2005-07105-C03-03 and 01) project (Spain).

\section{APPENDIX}

The extraterrestrial solar radiation for 24-hour period, $\mathrm{Ra}$, expressed in $\mathrm{MJ} \mathrm{m}^{-2} \mathrm{day}^{-1}$ can be determined over flat terrain by the expression [27]

$\mathrm{Ra}=37.6\left[1+0.33 \cos (0.0172 \mathrm{k}]\left[\omega_{\mathrm{s}} \sin \varphi \sin \delta+\cos \varphi \cos \delta\right.\right.$ $\left.\sin \omega_{\mathrm{s}}\right]$

where $\mathrm{k}$ is the day number in year, $\delta, \varphi$ and $\omega_{\mathrm{s}}$ are the solar declination, the latitude (positive in northern hemisphere) and sunset hour angle, respectively, all expressed in radians. The solar declination and sunset hour angle can be determined as:

$\delta=0.409 \sin (0.0172 \mathrm{k}-1.39)$ and $\omega_{\mathrm{s}}=\operatorname{acos}(-\tan \varphi \tan \delta)$.

The slope of the saturation vapor pressure curve, $\Delta$, in $\mathrm{kPa} \mathrm{C}^{-1}$ can be determined as:

$\Delta=\left(2504 /(\mathrm{T}+237.2)^{2}\right) \exp (17.27 \mathrm{~T} /(\mathrm{T}+237.2))$

where $\mathrm{T}$, in $\mathrm{C}$, is the daily mean air temperature.

The soil heat flux, $\mathrm{G}$, in $\mathrm{MJ} \mathrm{m}^{-2}$ day $^{-1}$ for day $k$ was estimated as

$\mathrm{G}=0.38\left(\mathrm{~T}_{\mathrm{k}}-\mathrm{T}_{\mathrm{k}-1}\right)$

The 24-hour period net solar radiation, $\mathrm{R}_{\mathrm{n}}$, in $\mathrm{MJ} \mathrm{m}^{-2}$ day ${ }^{1}$ for the reference crop is

$\mathrm{R}_{\mathrm{n}}=(1-\alpha) \quad \mathrm{R}_{\mathrm{s}}-2.45 \cdot 10^{-9} \quad f\left[0.261\right.$ exp $\left(-7,7 \cdot 10^{-4} \mathrm{~T}^{2}\right)-$ $0,02]\left(\mathrm{T}_{\mathrm{kx}}^{4}-\mathrm{T}_{\mathrm{kn}}^{4}\right)$

where $\alpha$ is the albedo, $\alpha=0.23$, T is the mean daily temperature in $\mathrm{C}, \mathrm{T}_{\mathrm{kx}}$ and $\mathrm{T}_{\mathrm{kn}}$ are the maximum and minimum daily temperatures in Kelvin, respectively, and $f=\left(1.8 \cdot\left(\mathrm{R}_{\mathrm{s}} / \mathrm{R}_{\mathrm{a}}\right)\right)-$ 0.35 is a cloudiness factor. The Priestley and Taylor equation [31] to estimate evapotranspiration, $\mathrm{ET}_{\mathrm{o}}$, is expressed as

$\mathrm{ET}_{\mathrm{o}}=\beta \frac{\Delta}{\Delta+\gamma}\left(\mathrm{R}_{\mathrm{n}}-\mathrm{G}\right)$

For the reference crop at sites not short of water with noextreme climates and negligible advection of sensible heat flux, the coefficient $\beta$ can be set to, $\beta=1.26$ [24]. The parameter, $\gamma$, is the psychrometric constant. For a wide range of climates, $\gamma=0.066 \mathrm{kPa} \mathrm{C}^{-1}$. Regardless of the values assigned to the coefficients $\alpha$ and $\beta$ in Eqs. (A3), (A4) and (A5), they do not affect the comparisons between estimated and observed $\mathrm{ET}_{\mathrm{o}}$.

\section{REFERENCES}

[1] Monteith JL, Unsworth MH. Principles of Environmental physics. Chapman and Hall, NY. 1992.

[2] Grant RH, Hoogenboom G, Hubbard KG, Hollinger SE, Vanderlip RL. Ability to predict daily solar radiation values from interpolated climate records for use in crop simulation models. Agric Forest Meteorol 2004; 127: 65-75.

[3] Stockle C, Kjelgaard J, Bellochi G. Evaluation of estimated weather data for calculating Penman-Monteith reference crop evapotranspiration. Irrig Sci 2004; 23: 39-46.

[4] Punyawardena BVR, Kulasiri D. Stochastic Simulation of Solar Radiation from Sunshine Duration in Sri Lanka. Conference in Ag- ric Eng and Tech exhibition, ASAE and AESD Dhaka Bangladesh. 1997; 1: 121-128.

[5] Angström A. Solar and terrestrial radiation. Quart J R Met Soc 1924; 50:121-126.

[6] Glover J, McCulloch JSG. The empirical relationship between solar radiation and hours of sunshine. Quart J R Met Soc 1958; 84:172 175.

[7] Martinez-Lozano JA, Tena F, Onrubia JE, De la Rubia J. The historical evolution of the Angström formula and its modifications: review and bibliography. Agric Forest Meteorol 1984; 33: 109-128.

[8] Ravfeim KJA. Estimating solar radiation income from bright sunshine records. Quart J R Met Soc 1981; 107: 427-435.

[9] Supit I. Global radiation. Luxembourg: Office for Official Publication of the European Communities Agric Series Cat No:CL-NA15745_EN_C. 1994

[10] Bechini L, Ducco G, Donatelli M, Stein A. Modeling, interpolation and stochastic simulation in space and time of global solar radiation. Agric Ecosyst Environ 2000; 81: 26-42.

[11] Hunt LA, Kuchar L, Swanton CJ. Estimation of solar radiation for use in crop modelling. Agric Forest Meteorol 1998; 91: 293-300.

[12] Linacre E. Climate data and resources. A reference and guide. Routledge. London-NY. 1992.

[13] Liu DL, Scott BJ. Estimation of solar radiation in Australia from rainfall and temperature observations. Agric Forest Meteorol 2001; 106: 41-59.

[14] Meza F, Varas E. Estimation of mean monthly solar global radiation as a function of temperature. Agric Forest Meteorol 2000; 100: 231-241.

[15] Supit I, Van Kappel RR. A simple method to estimate global solar radiation. Sol Energy 1998; 63 (3): 147-160.

[16] Weber GR. On the seasonal variation of local relationships between temperature, temperature range, sunshine and cloudiness. Theor Appl Climatol 1994; 50: 15-22.

[17] Castellví F, Stockle CO, Mormeneo I, Villar JM. Testing the performance of different process to generate temperature and solar radiation. A case study at Lleida (Northeast Spain). Trans ASAE 2002; 45 (3): 571-580.

[18] Castellví F, Mormeneo I, Perez PJ. Generation of daily precipitation from standard climate data. A study case for Argentina. J Hydrol 2003; 289: 286-302

[19] Donatelli M, Bellochi G, Carlini L, Colauzzi M. CLIMA: A component-based weather generator. MODSIM 2005. Melbourne, 12 15 Dec. 2005. Australia. www. Sipeaa.it/ASP/ASP2/Clima.asp

[20] Richardson CW, Wright DA. WGEN: A model for generating daily weather variables. US Dept of Agric, Res Service, ARS-8. 1984.

[21] Hargreaves GL, Hargreaves GH, Riley JP. Irrigation water requirement for Senegal River Basin. J Irrig Drain Eng 1985; 111: 265-275

[22] Bristow KL, Campbell GS. On the relationship between incoming solar radiation and daily maximum and minimum temperature. $\mathrm{Ag}$ ric Forest Meteorol 1984; 31:150-166

[23] Castellví F. A new simple method to estimate the monthly and daily solar radiation. A study case in Lleida (a semiarid climate). Theor Appl Climatol 2001; 69: 231-238.

[24] Jensen ME, Burman RD, Allen RD. Evapotranspiration and irrigation water requirements. ASCE Manuals and Reports on Engineering Practices 70. American Society for Civil Engineers, NY. 1990.

[25] Brutsaert W. Evaporation into the atmosphere. D. Reidel PC, Holland. 1988.

[26] Wang J, Bras RL. A new method for estimation of sensible heat flux from air temperature. Water Resour Res 1998; 34 (9): 22812288.

[27] Allen RG, Pereira LS, Raes D, Smith M. Crop Evapotranspiration Guidelines for computing crop water requirements. FAO, Irrigation and Drainage 56, Roma. 1998.

[28] Donatelli M, Campbell GS. A simple model to estimate global solar radiation. Proceedings of the $5^{\text {th }}$ ESA Congress. Nitra. Slovak Republic. 1998; 133-134. Nitra.

[29] Essenwanger OM. General Climatology, 1B. Elements of Statistical Analysis. Elsevier Amsterdam-London-NY-Tokio. 1986

[30] Walker HM, Lev J. Statistical inference. Henry Holt and Company. NY. 1953.

[31] Priestley CHB, Taylor RT. On the assessment of surface heat flux and evaporation using large scale parameters. Mon Weather Rev 1972; 100: 81-92. 
[32] Hoogenboom G, Garcia y Garcia A. Evaluation of an improved daily solar radiation generator for the southeastern USA. Clim Res 2005; 29 (2): 91-102.

[33] Matalas NC. Mathematical assesment of synthetic hydrology. Water Resour Res 1967; 3(4): 937-945.
[34] Castellví F, Stockle CO, Ibañez M. Comparing a Locally-calibrated Versus a Generalized Temperature weather generation. Trans ASAE. 2001; 44 (5): 1143-1148.

[35] Thornthwaite CW, Holzman B. The determination of evaporation from land and water surfaces. Mon Weather Rev 1939; 76: 4-11.

(C) F. Castellvi; Licensee Bentham Open.

This is an open access article licensed under the terms of the Creative Commons Attribution Non-Commercial License (http://creativecommons.org/licenses/by$\mathrm{nc} / 3.0 /$ ) which permits unrestricted, non-commercial use, distribution and reproduction in any medium, provided the work is properly cited. 